\title{
sciendo
}

Current Issues in Pharmacy and Medical Sciences

Formerly ANNALES UNIVERSITATIS MARIAE CURIE-SKLODOWSKA, SECTIO DDD, PHARMACIA

\section{Haemophilus influenzae and Haemophilus parainfluenzae occurrence in the ear effusion in pediatric patients prone to recurrent respiratory tract infections (RRTI) and with otitis media with effusion (OME)}

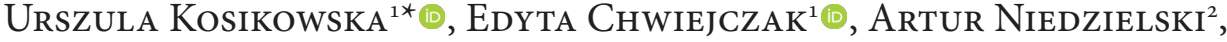

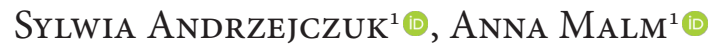

\author{
${ }^{1}$ Department of Pharmaceutical Microbiology, Medical University of Lublin, Poland \\ 2 Department of Pediatric Otolaryngology, Phoniatrics and Audiology, Medical University of Lublin, Poland
}

\section{ARTICLE INFO \\ Received 06 May 2019 \\ Accepted 30 September 2019}

\section{Keywords:}

Haemophilus influenzae, Haemophilus parainfluenzae, pediatric patients, otitis media with effusion, bacterial cell surface hydrophobicity.

\begin{abstract}
Introduction. Haemophilus influenzae and Haemophilus parainfluenzae are known as human-restricted respiratory microbiota representatives. The aim of the present paper was to assay haemophili prevalence in middle ear effusion specimens in pediatric patients with otitis media with effusion (OME).

Methods. A total of 86 ear effusion specimens (from the left and right ear independently) were collected from 43 pediatric patients with OME. For comparison, 58 nasopharyngeal specimens were taken from 58 pediatric patients prone to recurrent respiratory tract infections (RRTI). Isolation and identification of haemophili biotypes and antimicrobial susceptibility was accomplished by standard microbiological methods. The cell surface hydrophobicity $(\mathrm{CSH})$ of isolates was assayed by the method of aggregation in ammonium sulfate (SAT).

Results. Haemophili were isolated in $25.6 \%$ (11/43) of all OME patients: in 5/43 (11.6\%) - H. influenzae (biotypes II, III), in 5/43 (11.6\%) - H. parainfluenzae, in 1/43 (2.3\%) - both species were found. Haemophili-positive nasopharyngeal specimen was found in $27 / 58$ (46.6\%) RRTI patients: in 19/58 (32.8\%) - H. influenzae, in 8/58 (13.8\%) $H$. parainfluenzae. About $90 \%$ of all haemophili isolates were characterised by extreme to strong CSH. Antimicrobial resistance occurred mainly among $H$. parainfluenzae $(80 \%)$ and to a much lower percentage among $H$. influenzae (33.3\%) isolates. The obtained data suggest that both $H$. influenzae and $H$. parainfluenzae can be involved in pathology of OME in pediatric patients. The high cell surface hydrophobicity can affect on the haemophili prevalence and ear colonization, and induces predisposition to the presence of these bacteria as a biofilm that serves as a virulence factor with great importance for the survival of these opportunistic bacteria and their persistence in the ear environment.
\end{abstract}

\section{INTRODUCTION}

Middle ear diseases in childhood, such as acute otitis media (AOM) or otitis media with effusion (OME; blue drum, glue ear) are a very common set of childhood diseases, and they have been studied extensively within the last decades [1-3]. AOM is connected with an inflammation of the middle ear, especially of the tympanic cavity, with

\footnotetext{
* Corresponding author

e-mail: urszula.kosikowska@umlub.pl
}

short duration of illness and an acute beginning. OME is the clinical term for the presence of fluid in the middle ear behind the intact eardrum and is characterized by a nonpurulent effusion that may be either mucoid (thick) or serous (thin) [4]. It is an inflammation of the middle ear without signs or symptoms of acute ear infection, pending beyond its intact eardrum and without systemic or otoscopic symptoms. An OME is the catchall term if the tympanic effusion persists for more than 3 months. Near chronic 
rhinosinusitis is a common disease of childhood, occurring most often between six months and four years of age. It is one of the most common causes of hearing loss in this age group.

According to literature [2,5-8], approximately $80-90 \%$ of all children have at least one episode of AOM or OME before school age. The disease is characterized by the presence of fluid in the tympanic cavity and progressive hearing loss. Effusion in the middle ear is often accompanied by upper respiratory tract infections and then is maintained only for a few days. In the course of chronic OME, affecting up to $75 \%$ of all children, effusion persists to 6 months and its spontaneous regression is much more rare. It is assumed that every tenth child in preschool and one in six school children has periodic or permanent hearing loss associated with OME $[5,6,9]$. The wide range and steady increase in the incidence of OME in the last fifteen years has forced multilateral and targeted prevention campaigns, as well as a search for optimal methods of treatment.

The pathogenesis of the disease is not clearly explained and is probably multifactorial. The development of recurrent and chronic otitis is affected by several host factors, such as immunological disorders, recurrent upper respiratory tract infections, allergies, genetic predisposition, being male and also by environmental factors. The carriage of pathogenic microorganisms within upper airways in children during the first years of life depends on their immune system condition, as well as on various epidemiologic and socioeconomic factors [9,10]. Streptococcus pneumoniae, Haemophilus influenzae and Moraxella catarrhalis have commonly been identified as the bacterial pathogens in the majority of reports from acute otitis media (AOM) patients [11,12].

Respiratory microbiota may be the reservoir of opportunistic pathogens with high (e.g. H. influenzae) or low (e.g. H. parainfluenzae) pathogenicity $[10,13,14]$. Both these species types can be responsible for the acute and recurrent or chronic forms of respiratory infections, especially in young children [15-20].

The type of diseases caused by H. influenzae has changed considerably in recent years; both encapsulated and nontypeable $H$. influenzae (NTHi) remains the most common pathogens to cause respiratory infections (e.g. acute respiratory infection, pneumonia, otitis media), or invasive infections (e.g. bacteremia, meningitis) [17]. H. influenzae was the most frequently associated bacterium for patients with chronic OME, recurrent AOM and AOM with treatment failure [12,21-23]. Additionally, Cardines et al. [24] identified a case of meningitis due to $H$. parainfluenzae in an adult with a 3-day history of acute otitis media.

The aim of our study was to ascertain $H$. influenzae and/ or $H$. parainfluenzae prevalence in a group of pediatric patients diagnosed with chronic otitis media with effusion (OME) and underwent myringotomy, as well as to detect within this patient group, those prone to recurrent respiratory tract infections (RRTI) and without OME. Additionally, the antimicrobial sensitivity and cell surface hydrophobicity preferring to biofilm formation of selected haemophili isolates were assessed.

\section{MATERIAL AND METHODS}

Forty-three children aged from 2 to 6 years old (Female 16, Male - 27), diagnosed with chronic otitis media with effusion (OME) were enrolled to the study. These OME patients were qualified for myringotomy - the surgical incision of the tympanic membrane with simultaneous removal of pathologic secretions. Studies were made during routine hospital procedures using to evaluate of OME, and swabs embodiment from the upper airways were not included.

None of the patients had active rhinosinusitis at the time of aspiration, but had antimicrobial therapy during thirty days before surgery. In the course of treatment, with a surgical microscope, a myringotomy incision was made in the tympanic membrane. Under direct visualization, the effusion was aspirated through sterile polyethylene tubing attached to a disposable middle-ear fluid collector. The physicians who were in charge of the patients were responsible for the diagnostic procedures and all decisions regarding treatment and follow-up. The study was approved by the Ethical Committee of Medical University of Lublin (No. KE-0254/75/2011). A total of 86 middle-ear effusions (two samples from each single patient - from right and left ear independently) were collected intra-operatively for microbiology. The collecting of the effusion was done after cleaning and disinfection of the external auditory canal and tympanic membrane with $70 \%$ solution of alcohol; then the tympanic membrane was cut it in the posterolateral quadrant, using an operating microscope. Material was collected under pressure using a sterile disposable Polymed Mucus Extractor sampling set (Poly Pedicure Ltd.). Next, the collected specimens were transported to the Department of Pharmaceutical Microbiology, Medical University of Lublin, where further tests were carried out.

In some of the work making up this study, a group of 58 of pediatric patients aged from 3 to 6 years old (Female 22 , Male -36$)$ prone to recurrent respiratory tract infections (RRTI, $\geq 3$ episodes/year) and without OME was also included. A total of 58 nasopharyngeal specimens were taken from RRTI-patients who did not have active rhinosinusitis at the time of study, or had not been admitted to hospital for at least three months or had antimicrobial treatment at least thirty days before study.

All collected specimens taken from the nasopharynx and ear effusion were immediately placed onto the selective Haemophilus chocolate agar (BioMerieux, France) in the direction of haemophili, and then cultured in the appropriate atmosphere with an increased $\mathrm{CO}_{2}$ concentration for $24-48 \mathrm{hrs}$ at $35^{\circ} \mathrm{C}$. After incubation, the growth of bacteria in the form of individual colonies or from abundant to a very abundant number of colonies on chocolate agar was observed. Haemophili rods with the same morphology of colonies growing on chocolate agar were treated as the same morphotype and identified on the basis of routine diagnostic methods (macroscopic, microscopic or biochemical assays). The growth requirement, biochemical characteristics, cell surface hydrophobicity (CSH) and antimicrobials sensitivity were assessed for the tested bacteria. 
For the primarily identification of isolated morphotypes, growth factors requirements were evaluated on TSA (Tripticasein Soy Lab-Agar, Biocorp, Poland) medium. Diagnostic discs (Oxoid, England) with hemin ( $\mathrm{X}$ factor), nicotinamide adenine dinucleotide ( $\mathrm{V}$ factor), and both $\mathrm{X}$ and $\mathrm{V}$ factors were used. Next, biochemical identification of Gram-negative isolates was carried out using the API NH microtest (bioMérieux, France). Haemophili isolates were assigned to I - VIII biotypes on the basis of indole production, urease activity and ornithine decarboxylase activity.

Cell surface hydrophobicity (CSH) assay. Herein, spontaneous aggregation of bacterial cells was carried out in $0.85 \% \mathrm{NaCl}$. A positive test result was recorded when the microorganisms remained clumped, and a negative test result was assigned when a smooth turbid suspension formed after gentle vortexing. The auto-aggregation assay was done by dispensing $20 \mu \mathrm{l}$ of a bacterial suspension, resuspended in $20 \mu \mathrm{l}$ of the phosphate-buffered saline (PBS) on a glass slide. Auto-aggregation of bacteria was observed against a spotlight by manually rotating the droplet for up to $1 \mathrm{~min}$ at room temperature. Bacterial suspensions that remained turbid and homogeneous were considered non-auto-aggregative, while bacterial suspensions presenting clumped cells were considered auto-aggregative [15].

For quantifying the hydrophobic cell surface properties of haemophili isolates, the salt aggregation test (SAT) according to [18] was used. Twofold serial dilutions of $\left(\mathrm{NH}_{4}\right)_{2} \mathrm{SO}_{4}$ (ammonium sulfate, Avantor Performance Materials, Poland) in PBS ranging from 0 to $3.2 \mathrm{M}$ [final concentration], and bacterial cell suspensions from HAEM agar-grown cultures resuspended in PBS (with very high density in about 9-10 McFarland standard) were prepared. Twenty-microliter aliquots of each ammonium sulfate solution were subsequently placed on glass slides and mixed thoroughly with $20 \mu \mathrm{l}$ of bacterial suspensions for visible aggregation by "salting out". Test results were interpreted taking into account the lowest concentration of ammonium sulfate, wherein the tested strains underwent aggregation (SAT value). The surface hydrophobity of bacteria was classified as follows, according to SAT value: (i) PBS alone extremely hydrophobic surface, (ii) $<0.4 \mathrm{M}$ - very strong hydrophobic surface, (iii) $0.4 \mathrm{M}-1.0 \mathrm{M}$ - strong hydrophobic surface, (iv) 1.2 M-1.6 M - hydrophobic surface, (v) $\geq 1,8$ $\mathrm{M}$ - hydrophilic surface.

Antimicrobial sensitivity assay. Antibiotic sensitivities of haemophili isolates were determined by the disc diffusion method, by means of Haemophilus Test Medium (HTM, Oxoid, England) according to the Clinical Laboratory Standards Institute (CLSI) recommendation for Haemophilus species [19]. Direct colony suspensions standardized to 0.5 McFarland $\left(\sim 10^{8} \mathrm{CFU} / \mathrm{ml}\right)$ were prepared using the colonies from an overnight HAEM agar incubation at $35^{\circ} \mathrm{C}$ in the atmosphere with about 5\% $\mathrm{CO}_{2}$. H. influenzae ATCC10211 was used to verify the growth promotion properties of HTM. Different discs with antimicrobial agents (BD BBL, Becton Dickinson and Company, USA), namely ampicillin, amoxicillin-clavulanic acid, ampicillin-sulbactam, cefazoline, cefuroxime, cefotaxime, ceftazidime, imipenem, aztreoname, azithromycin, amikacin, tetracycline, trimethoprim/sulfamethoxazole, ciprofloxacin, gentamycin were used. Isolates resistant to ampicillin were screened for betalactamase production by applying the Pen test (API NH, bioMerieux, France) and nitrocefin by means of the chromogenic cephalosporin method (Cefinase disks, BD BBL, Becton Dickinson and Company, USA).

\section{Statistical analysis}

Data processing and analysis were achieved through Stat-Soft. Inc Statistica 2010 for Windows. Frequencies of colonization and isolation of bacteria in the follow-up were compared with those at ear effusion by means of Fisher's test. Relative risk (RR) and their 95\% confidence intervals (CIs) were calculated. A $p$ value $\leq 0.05$ was considered as statistically significant.

\section{RESULTS}

\section{The frequency of patient colonization}

As shown in Table 1, haemophili were found in 11/43 (25.6\%) pediatric patients with OME in the ear effusion specimens: in 5/43 (11.6\%) patients with $H$. influenzae alone and in $5 / 43(11.6 \%)$ patients with only $H$. parainfluenzae, while in $1 / 43(2.3 \%)$ patients, $H$. influenzae together with $H$. parainfluenzae were found. In comparison, haemophilipositive nasopharyngeal specimen were discovered in 27/58 (46.6\%) of all RRTI-patients: $19 / 58(32.8 \%)$ of all patients were colonized by $H$. influenzae and 8/58 (13.8\%) were colonized by $H$. parainfluenzae, in $1 / 49(2 \%)$, non-identified Haemophilus spp. was collected.

Table 1. The prevalence of haemophili-positive specimens in the middle ear-effusion taken from pediatric patients with otitis media effusion (OME) who had undergone myringotomy, and in the nasopharyngeal swabs taken from pediatric patients prone to recurrent respiratory tract infections, but without OME

\begin{tabular}{|l|c|c|c|c|}
\hline $\begin{array}{c}\text { Group } \\
\text { of pediatric } \\
\text { patients }\end{array}$ & $\begin{array}{c}\text { Haemophilus } \\
\text { influenzae }\end{array}$ & $\begin{array}{c}\text { Haemophilus } \\
\text { parainfluenzae }\end{array}$ & $\begin{array}{c}\text { Haemophilus } \\
\text { influenzae } \\
\text { together with } \\
\text { Haemophilus } \\
\text { parainfluenzae }\end{array}$ & $\begin{array}{c}\text { Total number } \\
\text { of colonized } \\
\text { patients }\end{array}$ \\
\hline $\begin{array}{c}\text { RRTI patients } \\
(\mathrm{n}=58)\end{array}$ & $19(32.8)$ & $8(13.8)$ & $0(0)$ & $27(46.6)$ \\
\hline $\begin{array}{c}\text { OME patients } \\
(\mathrm{n}=43)\end{array}$ & $5(11.6)$ & $5(11.6)$ & $1(2.3)$ & $11(27.9)$ \\
\hline$p$ value & 0.0177 & 1.000 & $\mathrm{nd}$ & 0.0387 \\
\hline $\mathrm{RR}$ & 1.563 & 1.186 & $\mathrm{nd}$ & 1.444 \\
\hline $95 \% \mathrm{CI}$ & $1.156-2.113$ & $0.4169-3.375$ & $\mathrm{nd}$ & $1.046-1.994$ \\
\hline
\end{tabular}

Statistically significant differences $(p=0.0387)$ were observed in the number of pediatric patients with OME colonized by haemophili in the ear effusion (11/43, 27.9\%), as compared to RRTI-patients colonized by these bacteria in the nasopharynx $(27 / 58,46.6 \%)$. Similarly, statistically significant differences were seen in the number of patients colonized by $H$. influenzae $(6 / 43,13.95 \%$ vs. 19/58, 32.8\%; $p=0.0177)$, but not by $H$. parainfluenzae $(p=1.000)$. There were no differences between the frequency of haemophilipositive ear effusion specimens taken from Male and Female $(8 / 27,30 \%$ vs. $3 / 21,14.3 \%, p>0.1)$. 


\section{Haemophili isolates characteristics}

Haemophili phenotypes were differentiated based on observable properties in the growth morphology (e.g. the shape and size of the colony, smooth or rough surface, texture, colony elevation), on a set of biochemical reactions (according to API NH results) and antimicrobial susceptibility results.

As was shown in Figure 1, in 17/86 (19.8\%) of all haemophili-positive ear-effusion specimens, a total of 19 haemophili isolates were identified: $9 / 19(47.4 \%)$ as $H$. influenzae (designated as two biotypes: II - 3 isolates and III -6 isolates) and 10/19 (52.6\%) as H. parainfluenzae (designated as biotypes: I -3 isolates, II -5 isolates, III -1 isolate, and V -1 isolate).

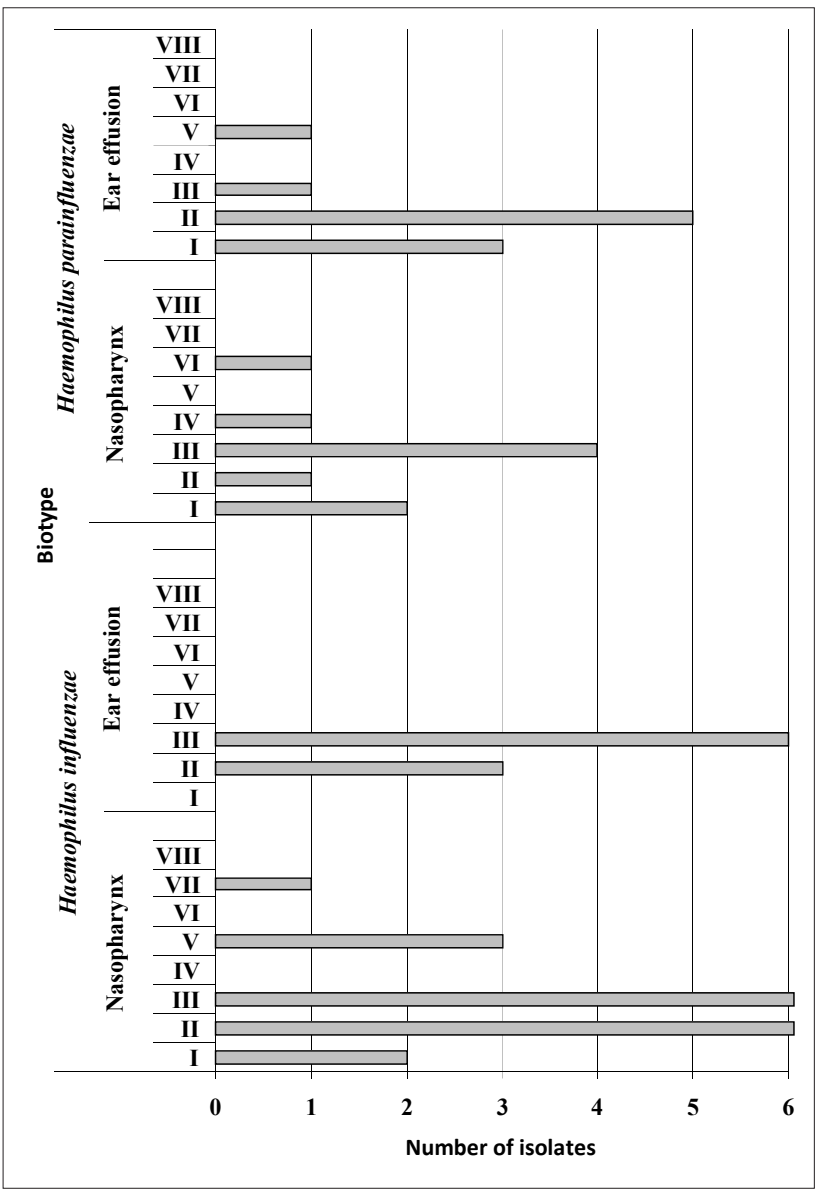

Figure 1. Haemophilus influenzae and Haemophilus parainfluenzae biotypes occurrence in the middle ear effusion specimens taken from pediatric patients with otitis media with effusion (OME) who qualified for myringotomy, and from the nasopharynx of RRTI patients

Among a total of 19 haemophili isolates $(9-H$. influenzae and $10-H$. parainfluenzae) selected in the ear effusion specimens of OME patients, 11/19 (57.9\%) isolates were detected as resistant to antimicrobials (Table 2). This resistance occurred mainly among isolates of $H$. parainfluenzae $(8 / 10,80 \%)$ and in much lower percentage among isolates of $H$. influenzae (3/9, 33.3\%). As was detected, 6/11 (54.5\%) isolates were ampicillin-resistant and beta-lactamase (penicillinase) positive, including 3/11 (27.3\%) H. influenzae and $3 / 10(27.3 \%) H$. parainfluenzae strains.
The same biotypes, together with the same antimicrobials sensitivity profiles of $H$. influenzae and $H$. parainfluenzae, were found in $3 / 11(27.3 \%)$ and $1 / 11(9.1 \%)$ of all patients with colonized OME, respectively, both in the left and right ears (Table 2). In 1/11 (9.1\%) of all patients, H. parainfluenzae isolates independently selected from the left and right ear had the same biotype (I), but they differed in the antimicrobials susceptibility.

Table 2. Haemophili characteristics in the ear effusion specimens taken from patients with otitis media with effusion and who qualified for myringotomy

\begin{tabular}{|c|c|c|c|c|c|}
\hline $\begin{array}{l}\text { No. of } \\
\text { patient }\end{array}$ & $\begin{array}{c}\text { Ear with } \\
\text { haemophili } \\
\text { isolation }\end{array}$ & Species & Biotype & $\begin{array}{c}\text { Cell surface } \\
\text { hydrophobicity }\end{array}$ & $\begin{array}{l}\text { Resistance } \\
\text { profile }\end{array}$ \\
\hline \multirow{2}{*}{11} & Left & $\begin{array}{l}\text { Haemophilus } \\
\text { parainfluenzae }\end{array}$ & II & $\begin{array}{c}\text { extremely } \\
\text { hydrophobic }\end{array}$ & $\begin{array}{c}\text { Am (Pen } \text { Pess }) \\
\text { SxtTe }\end{array}$ \\
\hline & Right & $\begin{array}{l}\text { Haemophilus } \\
\text { parainfluenzae }\end{array}$ & II & $\begin{array}{c}\text { extremely } \\
\text { hydrophobic }\end{array}$ & $\begin{array}{c}\text { Am }\left(\mathrm{Pen}_{\text {pos }}\right) \\
\text { SxtTe }\end{array}$ \\
\hline \multirow{2}{*}{12} & Left & $\begin{array}{l}\text { Haemophilus } \\
\text { parainfluenzae }\end{array}$ & III & $\begin{array}{c}\text { very strong } \\
\text { hydrophobic }\end{array}$ & $\mathrm{SxtCz}$ \\
\hline & Right & $\begin{array}{l}\text { Haemophilus } \\
\text { parainfluenzae }\end{array}$ & V & $\begin{array}{c}\text { very strong } \\
\text { hydrophobic }\end{array}$ & $\mathrm{Cz}$ \\
\hline \multirow{3}{*}{14} & \multirow{2}{*}{ Left } & $\begin{array}{l}\text { Haemophilus } \\
\text { parainfluenzae }\end{array}$ & II & $\begin{array}{c}\text { extremely } \\
\text { hydrophobic }\end{array}$ & Sxt \\
\hline & & \begin{tabular}{|l|}
$\begin{array}{l}\text { Haemophilus } \\
\text { influenzae }\end{array}$ \\
\end{tabular} & III & $\begin{array}{c}\text { extremely } \\
\text { hydrophobic }\end{array}$ & - \\
\hline & Right & $\mathrm{ng}$ & - & - & - \\
\hline \multirow[b]{2}{*}{15} & Left & $\mathrm{ng}$ & - & - & - \\
\hline & Right & $\begin{array}{l}\text { Haemophilus } \\
\text { parainfluenzae }\end{array}$ & II & $\begin{array}{c}\text { extremely } \\
\text { hydrophobic }\end{array}$ & - \\
\hline \multirow{2}{*}{16} & Left & $\begin{array}{l}\text { Haemophilus } \\
\text { parainfluenzae }\end{array}$ & I & $\begin{array}{c}\text { extremely } \\
\text { hydrophobic }\end{array}$ & - \\
\hline & Right & $\begin{array}{l}\text { Haemophilus } \\
\text { parainfluenzae }\end{array}$ & I & $\begin{array}{c}\text { extremely } \\
\text { hydrophobic }\end{array}$ & CzTe \\
\hline \multirow{3}{*}{17} & Left & $\mathrm{ng}$ & - & - & - \\
\hline & \multirow{2}{*}{ Right } & $\begin{array}{l}\text { Haemophilus } \\
\text { parainfluenzae }\end{array}$ & I & $\begin{array}{c}\text { extremely } \\
\text { hydrophobic }\end{array}$ & $\begin{array}{c}\text { Am }\left(\mathrm{Pen}_{\text {pos }}\right) \\
\text { SxtTe }\end{array}$ \\
\hline & & $\begin{array}{l}\text { Haemophilus } \\
\text { parainfluenzae }\end{array}$ & II & $\begin{array}{c}\text { extremely } \\
\text { hydrophobic }\end{array}$ & SxtTe \\
\hline \multirow[b]{2}{*}{21} & Left & $\mathrm{ng}$ & - & - & - \\
\hline & Right & $\begin{array}{l}\text { Haemophilus } \\
\text { influenzae }\end{array}$ & II & $\begin{array}{c}\text { extremely } \\
\text { hydrophobic }\end{array}$ & Am $\left(\operatorname{Pen}_{p o s}\right)$ \\
\hline \multirow{2}{*}{24} & Left & $\begin{array}{l}\text { Haemophilus } \\
\text { influenzae }\end{array}$ & III & $\begin{array}{c}\text { strong } \\
\text { hydrophobic }\end{array}$ & - \\
\hline & Right & $\begin{array}{l}\text { Haemophilus } \\
\text { influenzae }\end{array}$ & III & $\begin{array}{c}\text { strong } \\
\text { hydrophobic }\end{array}$ & - \\
\hline \multirow{2}{*}{32} & Left & $\begin{array}{l}\text { Haemophilus } \\
\text { influenzae }\end{array}$ & II & $\begin{array}{c}\text { strong } \\
\text { hydrophobic }\end{array}$ & $A m\left(\operatorname{Pen}_{\text {pos }}\right)$ \\
\hline & Right & $\begin{array}{l}\text { Haemophilus } \\
\text { influenzae }\end{array}$ & II & $\begin{array}{c}\text { strong } \\
\text { hydrophobic }\end{array}$ & $A m\left(\operatorname{Pen}_{\text {pos }}\right)$ \\
\hline \multirow[t]{2}{*}{39} & Left & $\begin{array}{l}\text { Haemophilus } \\
\text { influenzae }\end{array}$ & III & $\begin{array}{c}\text { extremely } \\
\text { hydrophobic }\end{array}$ & \\
\hline & Right & $\mathrm{ng}$ & - & - & - \\
\hline \multirow{2}{*}{43} & Left & $\begin{array}{l}\text { Haemophilus } \\
\text { influenzae }\end{array}$ & III & hydrophilic & - \\
\hline & Right & $\begin{array}{l}\text { Haemophilus } \\
\text { influenzae }\end{array}$ & III & hydrophilic & - \\
\hline
\end{tabular}

Abbreviations: ng - no growth; Am - ampicillin; Cz - cefazoline; Sxt trimethoprim/sulfametoksazol; $\mathrm{Te}$ - tetracycline; $\mathrm{Pen}_{\mathrm{pos}}$ - penicillinase-positive

In 27/58 (46.6\%) of all nasopharyngeal specimens taken in RRTI patients, 29 haemophili isolates were selected (Figure 1). Thus, 20/29 (69\%) isolates were classified as H. influenzae (biotypes I, II, III, V and VII) and 9/29 (31\%) as H. parainfluenzae (biotypes I, II, III, IV and VI). 1/20 (5\%) H. influenzae and 2/9 (22.2\%) H. parainfluenzae isolates were beta-lactamase-positive.

As was evaluated on the basis of SAT value (Table 2), a total of 17/19 (89.5\%) haemophili isolates in OME patients were characterized by their hydrophobic cell surfaces: these were all the selected $H$. parainfluenzae isolates $(10 / 10$, $100 \%$ ) and a majority of $H$. influenzae isolates $-7 / 9(77.8 \%)$. 
Broken down, 11/19 (57.9\%) of all isolates were characterized by extremely hydrophobic cell surface (H. influenzae $3, H$. parainfluenzae -8 isolates), $2 / 19(10.5 \%)$ isolates - by very strong hydrophobic cell surface (only $H$. parainfluenzae -2 isolates), $4 / 19$ (21.1\%) isolates - by strong hydrophobic cell surface (only $H$. influenzae), and 2/19 (10.5\%) isolates - by hydrophilic cell surface (only H. influenzae).

\section{DISCUSSION}

Our study indicates that about $28 \%$ of all OME pediatric patients were colonized by haemophili in the ear effusion, either by $H$. influenzae and $H$. parainfluenzae. On the basis of our results, we suggest that both $H$. influenzae and $H$. parainfluenzae are etiological agents of OME disease in young children. Accordingly, their high cell surface hydrophobicity predisposes to the presence of these bacteria in biofilm. This can be a pathogenic factor of great importance for the survival of these opportunistic bacteria and their persistence in the ear environment.

Although respiratory viruses have an important role in the pathogenesis of OME [25], the isolation of bacteria from ear effusion specimens has long been the gold standard for the etiologic diagnosis of the causative pathogens for acute otitis media. Our work reveals that only approximately $50-60 \%$ of all diagnostic samples were culture-positive for any of the major causative pathogens [21-23,26]. According to Klein et al. [27], although bacterial pathogens have been isolated in the majority of cases, cultures have still yielded negative results for pathogenic bacteria in about $12 \%-35 \%$ of all cases.

Haemophili, mainly non-typeable $H$. influenzae (NTHi), is a leading causative pathogen responsible for acute otitis media [21-23]. The presence of $H$. parainfluenzae in the respiratory tract microbiota composition also may have a pathogenic role [28]. Although $H$. parainfluenzae has not been considered of much clinical importance in humans, the case describe by Cardines et al. [24] confirms that it can be regarded as an opportunistic pathogen able to cause life-threatening infections, not only in children, but also in adults, especially when underlying conditions are present. Cardines et al. [24] supposed that the same H. parainfluen$z a e$ isolate was responsible for both meningitis and acute otitis media, although they did not prove this hypothesis since no culture of the middle ear fluid was performed. In our opinion, the near pathogenic role of these bacteria can cause other negative results due to their presence, such as co-colonization by other microorganisms. The causative pathogens frequently populate the nasopharynx and bring infection to the middle ear via the Eustachian tubes [29]. It is recognized that middle-ear disorders are related to the presence of typical pathogens such as Streptococcus pneumoniae, H. influenzae, Moraxella catarrhalis or Staphylococus aureus - all of which commonly colonized the mucous membranes of the upper airways $[11,13,30]$.

Some differences were demonstrated in the distribution of haemophili biotypes and number of antimicrobial resistant isolates. According to our results, compared with only two H. influenzae biotypes (II and III) detected in the ear effusion specimens in OME patients, a greater diversity of biotypes (mainly II and III, and rarely I, V or VII biotype) of this species was observed in the nasopharyngeal specimens in RRTI patients. These differences were lower among $H$. parainfluenzae biotypes selected in the ear effusion specimens (mainly I and II, and rarely III and V) and in the nasopharyngeal specimens (mainly I and III, and rarely II, IV, VI) in these two groups of children. All beta-lactamase producing $H$. influenzae isolates were classified as biotype II and were ampicillin-resistant, while $H$. parainfluenzae isolates were classified as biotypes I and II - with resistance against ampicillin, trimethoprim/sulfamethoxazole and tetracycline.

Other authors have reported the oropharyngeal prevalence of mainly I and II biotypes of $H$. parainfluenzae compared to the low frequency of the other biotypes of this species $(31 ; 32 ; 33 ; 34)$. For example, the $H$. parainfluenzae isolate classified as biotype I was found associated with isolates from healthy carriers in a previous report [14]. As found by other authors [31,34,35], biotypes I and II constituted most of $H$. parainfluenzae isolates in patients with other respiratory diseases such as chronic bronchitis or cystic fibrosis.

High cell surface hydrophobicity was shown for isolated haemophili strains through use of the SAT method. The adherence capacity of bacteria to host cells depends on the bacterial surface properties such as hydrophobicity [36,37]. A more hydrophobic nature of cell surface usually may be regarded as a most relevant parameter for the maximum capability of biofilm formation of microbes [38]. Medical biofilms are involved in a number of chronic infections, including otitis media with effusion (OME) and chronic rhinosinusitis (CRS), which are common pediatric infectious diseases. Many features of otitis media support biofilm ear infection. This is formed by bacteria growing in slimeenclosed aggregates and provides an explanation for the lack of success of antibiotic therapy, the presence of negative bacterial cultures, and persistence of bacteria in the middleear space between acute episodes and local inflammatory responses to persistent bacteria [39]. The ability to form a biofilm by opportunistic coagulase-negative staphylococci strains emphasizes the pathogenic character of these strains in some cases of otitis media with effusion. More detailed studies on the ability to form biofilm by haemophili rods isolated from patients with OME will continue in the future. The high ability to grow in biofilm form especially of $H$. parainfluenzae and at low degree of $H$. influenzae was shown during our studies in pediatric patients with recurrent respiratory infections undergoing adenoidectomy [40], as well as in adult patients with sarcoidosis [41]. Bacteria in biofilms are generally well protected against environmental compounds, antimicrobials and the host immune system, and this is the reason why they are extremely difficult to eradicate [42-45].

\section{CONCLUSIONS}

The obtained data suggest the role of $H$. parainfluenzae and H. influenzae in OME pathology in pediatric patients. In these, bacterial high cell surface hydrophobicity can predispose to ear colonization and the growth in biofilm form, and they are favored as an OME etiological factor. 


\section{ORCID iDs}

Urszula Kosikowska (Dhttps://orcid.org/0000-0003-4536-1750 Edyta Chwiejczak (1) https://orcid.org/0000-0003-2287-6786 Sylwia Andrzejczuk (Dhttps://orcid.org/0000-0001-6301-6059 Anna Malm (D)https://orcid.org/0000-0003-1503-7634

\section{REFERENCES}

1. Dhooge IJ. Acute Otitis Media in Children. In: Graham JM, Scadding GK, Bull PD, editors. Pediatric ENT. Heidelberg: Springer; 2007:399-420.

2. Robb PJ. Otitis Media With Effusion. In: Graham JM, Scadding GK, Bull PD, editors. Pediatric ENT. Heidelberg: Springer;2007:413-20.

3. Healy GB, Rosbe KW. Otitis Media and Middle Ear Effusions. In: Snow JB Jr, Ballenger JJ, editors. Ballenger's Otorhinolaryngology Head and Neck Surgery. Hamilton: BC Decker;2003:249-60.

4. Rosenfeld RM, Culpepper L, Doyle KJ. Clinical practice guideline: otitis media with effusion. Otolaryngol Head Neck Surg. 2004;130: 95-118.

5. Saki N, Rahim F, Nikakhlagh S, Sarafraz M, Jafarzadeh E. Quality of life in children with recurrent acute otitis media in southwestern of Iran. Otolar Head and Neck Surg. 2012;66:267-70.

6. Qureishi A, Lee Y, Belfield K, Birchall JP, Daniel M. Update on otitis media - prevention and treatment. Infect Drug Resist. 2014;7:15-24.

7. Tos M . Epidemiology and natural history of secretory otitis. Am J Otol. 1984;5:459-62.

8. Teele DW, Klein JO, Rosner B. Epidemiology of otitis media during the first seven years of life in children in greater Boston: a prospective, cohort study. J Infect Dis. 1989;160:83-94.

9. Minovi A, Dazert S. Diseases of the middle ear in childhood. GMS Curr Top Otorhinolaryngol Head Neck Surg. 2014;13(11).

10. Bogaert D et al. Variability and diversity of nasopharyngeal microbiota in children: a metagenomic analysis. PLoS One. 2011;6: 17035.

11. Massa HM, Cripps AW, Lehmann D. Otitis media: viruses, bacteria, biofilms and vaccines. Med J Aust. 2009;191:44-9.

12. Ngo CC, Massa HM, Thornton RB, Cripps AW. Predominant bacteria detected from the middle ear fluid of children experiencing otitis media: a systematic review. PLoS One. 2016;11:e0150949.

13. Khoramrooz SS et al. Frequency of Alloicoccus otitidis, Streptococcus pneumoniae, Moraxella catarrhalis and Haemophilus influenzae in children with otitis media with effusion (OME) in Iranian patients. Auris Nasus Larynx. 2012;39:369-73.

14. Privitera A et al. Molecular epidemiology and phylogenetic analysis of Haemophilus parainfluenzae from chronic obstructive pulmonary disease exacerbations. Eur J Epidemiol. 1998;14:405-12.

15. Ariza Jiménez AB, Moreno-Perez D, Núñez Cuadros EA. Invasive disease caused by Haemophilus parainfluenzae III in a child with uropathy. J Med Microbiol. 2013;62:792-3.

16. Barkai G, Leibovitz E, Givon-Lavi N, Dagan R. Potential contribution by nontypable Haemophilus influenzae in protracted and recurrent acute otitis media. Pediatr Infect Dis J. 2009;28:466-71.

17. Berndsen MR, Erlendsdóttir H, Gottfredsson M. Evolving epidemiology of invasive Haemophilus infections in the postvaccination era: results from a long-term population-based study. Clin Microbiol Infect. 2012;18:918-23.

18. Ladhani S, Slack MP, Heath PT, von Gottberg A, Chandra M, Ramsay ME. Invasive Haemophilus influenzae disease, Europe, 1996-2006. Emerging Infect Dis. 2010;16:455-63.

19. Mitchell JL, Hill SL. Immune response to Haemophilus parainfluenzae in patients with chronic obstructive lung disease. Clin Diagn Lab Immunol. 2000;7:25-30.

20. Rele M, Giles M, Daley AJ. Invasive Haemophilus parainfluenzae maternal-infant infections: an Australasian perspective and case report. Aust N Z J Obstet Gynaecol. 2006;46:258-60.

21. Howie VM, Ploussard JH, Lester RL Jr. Otitis media: a clinical and bacteriological correlation. Pediatrics. 1970;45:29-35.

22. Bluestone CD, Stephenson JS, Martin LM. Ten-year review of otitis media pathogens. Pediatr Infect Dis J. 1992;11:7-11.

23. Kilpi T, Herva E, Kaijalainen T, Syrjänen R, Takala AK. Bacteriology of acute otitis media in a cohort of Finnish children followed for the first two years of life. Pediatr Infect Dis J. 2001;20:654-62.
24. Cardines R, Giufrè M, Ciofi degli Atti ML, Accogli M, Mastrantonio P, Cerquetti M. Haemophilus parainfluenzae meningitis in an adult associated with acute otitis media. New Microbiol. 2009;32:213-5.

25. Chonmaitree T, Hendrickson KJ. Detection of respiratory viruses in the middle ear fluids of children with acute otitis media by multiplex reverse transcription-polymerase chain reaction assay. Pediatr Infect Dis J. 2000;19:258-60.

26. Casey JR, Pichichero ME. Changes in frequency and pathogens causing acute otitis media in 1995-2003. Pediatr Infect Dis J. 2004;23: 824-8.

27. Klein JO, Bluestone CD. Otitis media. In: Feigin RD, Cherry JD, Demmler GJ, Kaplan SL, editors. Textbook of pediatric infectious diseases 5. Philadelphia: Saunders;2004:215-35.

28. Goleva et al. The effects of airway microbiome on corticosteroid responsiveness in asthma. Am J Respir Crit Care Med. 2013;188: 1193-201.

29. Faden $\mathrm{H}$ et al. Relationship between nasopharyngeal colonization and the development of otitis media in children. Tonawanda/ Williamsville Pediatrics. J Infect Dis. 1997;175:1440-5.

30. Park CW et al. Detection rates of bacteria in chronic otitis media with effusion in children. J K Med Scien. 2004;19:735-8.

31. Watson KC, Kerr EJ, Hinks CA. Distribution of biotypes of Haemophilus influenzae and H. parainfluenzae in patients with cystic fibrosis. J Clin Pathol. 1985;38:750-53.

32. Houang et al. Comparison of genital and respiratory carriage of Haemophilus parainfluenzae in men. J Med Microbiol. 1989;28: 119-23.

33. Martel, AY, St-Laurent G, Dansereau LA, Bergeron MG. Isolation and biochemical characterization of Haemophilus species isolated simultaneously from the oropharyngeal and anogenital areas. J Clin Microbiol. 1989;27:1486-9.

34. Taylor DC et al. Biotypes of Haemophilus parainfluenzae from the respiratory secretions in chronic bronchitis. J Med Microbiol. 1992;36:279-82.

35. Rhind GB, Gould GA, Ahmad F, Croughan MJ, Calder MA. Haemophilus biotypes in respiratory disease. Thorax. 1987;42:151-2.

36. Knobloch JK, Von Osten H, Horstkotte MA, Rohde H, Mack D. Minimal attachment killing (MAK): a versatile method for susceptibility testing of attached biofilm-positive and -negative Staphylococcus epidermidis. Med Microbiol Immunol. 2002;191: 107-14.

37. Zhang XS, Garcia-Contreras R, Wood TK.. YcfR (BhsA) influences Escherichia coli biofilm formation through stress response and surface hydrophobicity. J Bacteriol. 2007;189:3051-62.

38. Das MP. Effect of cell surface hydrophobicity in microbial biofilm formation. Euro J Exp Bio. 2014;4: 254-6.

39. Paluch-Oleś J et al. The phenotypic and genetic biofilm formation characteristics of coagulase-negative staphylococci isolates in children with otitis media. I J of Pediatr Otorhinolar. 2011;75:126-30.

40. Kosikowska et al. Nasopharyngeal and adenoid colonization by Haemophilus influenzae and Haemophilus parainfluenzae in children undergoing adenoidectomy and the ability of bacterial isolates to biofilm production. Medicine. 2015;94:799.

41. Kosikowska et al. Changes in the prevalence and biofilm formation of Haemophilus influenzae and Haemophilus parainfluenzae from the respiratory microbiota of patients with sarcoidosis. BMC Infect Dis. 2016;16:449.

42. Burmolle M, Bahl MI, Jensen LB, Sorensen SJ, Hansen LH. Type 3 fimbriae, encoded by the conjugative plasmid pOLA52, enhance biofilm formation and transfer frequencies in Enterobacteriaceae strains. Microbiol. 2008;154:187-95.

43. Hoiby N, Bjarnsholt T, Givskov M, Molin S, Ciofu O. Antibiotic resistance of bacterial biofilms. Inter J Antimicrob Ag. 2010;35: 322-32.

44. Jensen PO, Givskov M, Bjarnsholt T, Moser C. The immune system vs. Pseudomonas aeruginosa biofilms. FEMS Immunol Med Mic. 2010;59:292-305.

45. Daniel M, Imtiaz-Umer S, Fergie N, Birchall JP, Bayston R. Bacterial involvement in otitis media with effusion. Int J Pediatr Otorhinolaryngol. 2012;76:1416-22. 